\title{
The Psychological Resources of "Self-Attainment» of Personality in Transcendent Situations of Being
}

\section{Психологічні ресурси самовіднайдення особистості у граничних ситуаціях буття}

\author{
Olena Shtepa \\ Ph.D. in Psychology, Assistant Professor, Ivan Franko Na- \\ tional University of Lviv, Lviv (Ukraine) \\ ORCID ID: https://orcid.org/0000-0002-5396-3279 \\ Researcher ID: S-9557-2018 \\ E-mail: Olena.Shtepa@lnu.edu.ua

\section{Олена Штепа} \\ Кандидат психологічних наук, доцент, Львівський націо- \\ нальний університет імені Івана Франка, м. Львів (Україна)
}

\section{ABSTRACT}

The aim of the article is defined to be the empirical description of the psychological resources of the personality in the transcendent situations of being.

Methods. The psychological survey was used alongside with a personality resourceful questionnaire, a psychological resource questionnaire, a test questionnaire for diagnosing indicators of existential resources, a questionnaire for virtues and character strengths, a questionnaire for coping with a crisis, a psychological well-being questionnaire, a coherence scale, methods for determining tolerance to uncertainty, and estimation methods and predicting the development of situations of interpersonal interaction. The methods of mathematical statistical analysis such as one-way analysis of variance, multivariate analysis, cluster analysis, classification analysis, and correlation

Address for correspondence, e-mail: kpnu_lab_ps@ukr.net Copyright: (C) Shtepa Olena

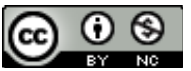

The article is licensed under CC BY-NC 4.0 International

(https://creativecommons.org/licenses/by-nc/4.0/)

(C) Shtepa Olena

DOI (article): https://doi.org/10.32626/2227-6246.2020-49.407-428 
analysis are applied. To implement the research tasks, the Bayer's model was applied, which implies the transformation of the problem into the form possible for its resolution. Empirical modeling and verification methods are implemented.

The results of the research. Based on the data of discriminant and multivariate analysis, the structure of the psychological resources of the personality in transcendent situations of being is determined, which contains, in fact, psychological resources and indicators of the ability to operate them (love, responsibility, knowledge of one's resources, the ability to update and invest one's resources), existential resources (mercy, faith), "strength of character» included in the virtue of self-control (prudence, self-control). The existential resource of faith is established to be a conditional indicator for determining the type of actualization of psychological resources of a personality in the transcendent situations of being. The system-forming factor of the resource system of the transcendent situations of being empirically substantiates system reflection. Psychological resources of personality's self-attainment are characterized as the structure of interconnected psychological, existential and relationship resources and "strength of character» that make it possible to bring the possible Self of a personality to the true Self, and cause the person to overcome the fear of true Self.

Conclusions. The closeness of the possible Self of a personality to its true Self is realized, when a person overcomes anxiety by solving a certain vital task. The resources of psychological survival, tolerance to uncertainty, personal resources, motivational resources of psychological well-being, a sense of connectedness were not included in the final model of psychological resources of self-attainment-again of a personality, since in transcendent situations of being it is impossible for a person to compare psychological losses and gains, because of rethinking of personal life. Based on the results of an empirical study, it is possible to refine or develop the psychological support of a personality in difficult life situations.

Key words: psychological resources of self-attainment of personality, transcendent situations of being, hardiness, personality fulfillment, system reflection.

\section{Вступ}

Результати визначення компонент ресурсної насиченості особистості в емпіричний спосіб (Штепа, 2020: 236) (C) Shtepa Olena

DOI (article): https://doi.org/10.32626/2227-6246.2020-49.407-428 
уможливили прикладні дослідження ресурсного контенту, зокрема ресурсів особистості, що актуалізуються і дають їй змогу здолати складні життєві ситуації. 3 погляду ресурсної зумовленості, нашу увагу привернули ситуації граничного буття, схарактеризовані Н. Хамітовим як «кризові стани людини, що приводять до актуалізації особистісного начала. <..> переосмисленні сенсу життя» (Хамітов, 2000: 254). Неусвідомлюване проживання граничних ситуацій буття може зумовити невротизацію особи, а усвідомлюване - зумовити зміни самоідентичності, особистісне розгортання (Хамітов, 2000: 254). Ситуаціями граничного буття Н. Хамітовим указано тугу, жах, самотність, відчай (2000: 253, 257, 260, 261). Узагальнюючи опис граничних ситуацій буття за Н. Хамітовим (2000: 253, 257, 260, 261), ми зробили висновок про те, що в окреслених ситуаціях ідеться, насамперед, щодо меж зовнішнього і внутрішнього «особистісного» та (не)прийняття людиною себе у такому межовому вимірі.

Вважаємо, що граничні ситуації буття відрізняються від стресових чи екстремальних. Зокрема, ресурсний критерій визначає стресові ситуації типу виклику, загрози, втрати (Абабков, 2004: 28). Водночас у граничних ситуаціях буття відбувається актуалізація особистості, розкриття їі глибинних можливостей (Хамітов, 2000: 252), джерелом яких $€$ екзистенційний досвід, що характеризується інтенційністю (Гришина, 2013: 384). На погляд авторів когнітивної лінгвістики, досвід людини функціонує як простір реалізації зв'язку між доменами значень і концептами мислетворення (Evans \& Green, 2006: 279, 303). У нашому теоретичному дослідженні доведено, що такими концептами, «кодами інтерпретації» контексту екзистенційної ситуації є психологічні ресурси (Штепа, 2018: 450), а Н. Низовських доведено, що ресурси зумовлюють характер самозміни особистості (Низовских, 2014: 35).

На основі наведених фактів ми припустили наявність у людини психологічних ресурсів, що характеризують їі змі(C) Shtepa Olena DOI (article): https://doi.org/10.32626/2227-6246.2020-49.407-428 
ни у граничних ситуаціях буття, а саме - здатність зрозуміти себе у контексті життя. Відтак, психологічні ресурси особистості, що актуалізуються саме у граничних ситуаціях буття, ми схарактеризували як психологічні ресурси самовіднайдення. Психологічні ресурси віднайдення людиною самої себе не є окремим видом особистісних ресурсів, а являють собою певну структуру взаємопов'язаних психологічних ресурсів різних типів, які уможливлюють максимальне наближення «Я»-можливого особи до їі істинного «Я». Своєю чергою, означений ефект зумовлює продуктивність проживання особою граничних ситуацій буття. «Я»-можливе ми тлумачимо, згідно з теорією Х. Маркус, як концептуальний зв'язок мотивації та саморозуміння людини (Markus, 1986: 956). Істинне «Я» схарактеризовано як таке, що властиве особі, яка пізнає себе (Корнаракис, 2016: 147).

Дотепер ресурсному контенту самовіднайдення особистості не було приділено уваги у теоретичних чи емпіричних дослідженнях, що, ймовірно, пов'язано з «некласичною трансформацією психології (Савчин, 2013: 134), переходом до екзистенціальної парадигми. Вочевидь, емпірично підтверджене знання психологічних ресурсів самовіднайдення особистості у граничних ситуаціях буття могло б бути корисним для психологів-практиків, оскільки надало б можливості апелювати до конкретних ресурсів.

Вважаємо, що верифікацію емпіричної моделі ситуації граничного буття можливо реалізувати за допомогою ідеї мотиваційної сегментації та зумовленості мотивації ситуаційним мисленням Д. Хоффман і Т. Новак (1997: 7), що характеризує певні мотиваційні стани людини через співвідношення рівня складності вимог ситуації та рівня наявних у неї навичок. Ми припустили, що емпіричним показником вимог ситуації до людини можна вважати життєстійкість, адже, за П. Тіліхом, така «відвага бути» пов'язана з дією людини всупереч онтологічній тривозі (Леонтьев \& Рассказова, 2006: 4). Емпіричним показником навичок особи мож(c) Shtepa Olena

DOI (article): https://doi.org/10.32626/2227-6246.2020-49.407-428 
на допустити особистісну здійсненність, яку схарактеризовано як «дискретний показник завершеності процесу особистісного самоздійснення відносно певної життєвої задачі, $<. .>$ який виявляється як ресурсний стан, що уможливлює втілення людиною розв'язання власної життєвої задачі у вчинку» (Штепа, 2018: 200). Відповідно, наближеність «Я»-можливого особи до її істинного «Я» здійснюється, коли рівень навичок людини відповідає вимогам ситуації, тобто коли розв'язанням певної життєвої задачі особа долає тривогу. Нездолана тривога виявляється відчаєм, який, згідно з Дж. Б’юдженталем (2001: 167), є шляхом вияву нереалізованого потенціалу, а виходом із нього є егоїстичне або альтруїстичне самозречення людини. Останнє ми вважаємо показником продуктивності проживання особою граничних ситуацій буття. На наш погляд, саме усвідомлювані людиною власні психологічні ресурси самовіднайдення уможливлюють долання страху самозміни.

Для змістовної характеристики змін у складній самоорганізованій системі, якою ми вважаємо суб'єктно сконструйовану граничну ситуацію буття (адже людина є суб'єктом інтерпретації (Пушкарьов, 2012: 20)), важливо схарактеризувати системоутворювальний чинник (Тітов, 2015: 21). Системоутворювальний чинник конкретизують як імперативний фактор, що характеризує корисний результат системи; його дія є достатньою для такої активації «поведінки» системи, щоб система перейшла на новий рівень функціонування (Анохін, 1973: 33).

Метою дослідження є емпіричне дескриптування психологічних ресурсів особистості у граничних ситуаціях буття.

\section{Завдання статті}

Завданнями статті встановлено такі: 1) емпірично визначити психологічні ресурси особистості у показниках дескриптування граничних ситуацій буття; 2) емпірично ви-

(C) Shtepa Olena

DOI (article): https://doi.org/10.32626/2227-6246.2020-49.407-428 
значити системоутворювальний чинник ресурсної системи граничних ситуацій буття.

\section{Методи та методики дослідження}

Для реалізації завдань дослідження застосовано модель Байєра, яка передбачає перетворення проблеми до уможливлюваного для розв'язання вигляду.

Емпіричними показниками дескриптування граничних ситуацій буття нами було визначено життєстійкість, особистісну здійсненність, відкритість досвіду, системну рефлексію. Включеність певного психологічного ресурсу до дискримінантних моделей життєстійкості, особистісної здійсненності, відкритості досвіду, системної рефлексії будо виведено за емпіричний критерій визначення психологічних ресурсів як ресурсів особистості саме у граничних ситуаціях буття. Рефлексію передбачено показником усвідомлюваності психологічних ресурсів самовіднайдення, а відкритість досвіду - показником готовності до самозміни.

Контент психологічних ресурсів було визначено за допомогою опитувальника психологічної ресурсності О. Штепи (психологічні ресурси); опитувальника втрат і набуття персональних ресурсів (розроблено Н. Водоп'яновою та М. Штейном на основі ресурсної концепції психологічного стресу i «консервування ресурсів» С. Хобфолла) (персональні ресурси); тест-опитувальника діагностики показників екзистенційних ресурсів особистості Є. Рязанцевої, анкети самооцінки «сил характеру», побудованої нами на основі опитувальника «Чесноти і сили характеру» (адаптація I. Буровіхіною, Д. Леонтьєвим, Є. Осіним методики Values in Action К. Петерсона і M. Селігмана), опитувальника стратегій подолання кризового стану М. Лаада (ресурси психологічного виживання); опитувальника психологічного благополуччя (адаптація С. Карсканової методики К. Ріфф) (мотиваційні ресурси); шкали когерентності А. Антоновскі в адаптації (c) Shtepa Olena

DOI (article): https://doi.org/10.32626/2227-6246.2020-49.407-428 
Є. Осіна, методики визначення (ін)толерантності до невизначеності С. Бадлера (адаптація Г. Солдатової, Л. Шайгерової), методики оцінки та прогнозування психологічного розвитку ситуацій міжособистісної взаємодії О. Бандаренко (ресурси взаємин).

Емпіричне дескриптування психологічних граничних ситуацій буття особистості було реалізовано за допомогою тесту життєстійкості (адаптація Д. Леонтьєвим і Є. Рассказовою опитувальника Hardiness Survey С. Мадді), опитувальника особистісної здійсненності О. Штепи, опитувальника рефлексії Д. Леонтьєва і Є. Осіна, шкали «відкритість досвіду» методики «Велика п’ятірка особистісних якостей» (адаптація А. Грецова).

Емпіричними критеріями системоутворювального чинника для ресурсної системи граничних ситуацій буття ми допустили такі: 1) включений до ресурсної системи граничних ситуацій буття; 2) зумовлює зміни усіх компонентів ресурсної системи граничних ситуацій буття; 3) є чинником життєстійкості й особистісної здійсненності; 4) є показником, за яким відрізняються між собою підгрупи досліджуваних за компонентами ресурсної системи граничних ситуацій буття.

У дослідженні було задіяно 420 осіб віком 21-67 років, із них $57 \%$ жінок, $43 \%$ чоловіків $(\mathrm{M}=42,3)$ (студенти IV-VI курсів і викладачі навчальних закладів III-IV ступенів, слухачі Інституту доуніверситетської та післядипломної освіти, слухачі Львівського «Університету третього віку», приватні підприємці малого бізнесу).

\section{Результати та дискусії}

Із метою емпірично визначити психологічні ресурси особистості у показниках дескриптування граничних ситуацій буття було застосовано дискримінантний аналіз 65 шкал психологічних ресурсів різних видів. Установлено, що 
дискримінантна модель за показником «загальний рівень життєстійкості» містить 55 психологічних ресурсів (Wilks' Lambda 0,13), за показником «загальний рівень особистісної здійсненності» - 58 психологічних ресурсів (Wilks' Lambda 0,11), за показником «системна рефлексія» - 63 психологічні ресурси (Wilks' Lambda 0,11), за показником «відкритість досвіду» - 29 психологічних ресурсів (Wilks' Lambda 0,67). Психологічними ресурсами, включеними усіма чотирма означеними дискримінантними моделями, були такі: любов, прагнення мудрості, відповідальність, знання власних ресурсів, уміння оновлювати власні ресурси, уміння вміщувати власні ресурси, цілі у житті, самоприйняття, милосердя, прийняття, віра, наполегливість, енергійність, причетність до спільної справи, скромність, розсудливість, самоконтроль, вдячність, почуття гумору, стосунки, персональна ресурсність, смислові набуття, екзистенційні набуття (усього 23 ресурси).

Із метою уточнити структуру психологічних ресурсів особистості у граничних ситуаціях буття застосовано багатофакторний аналіз, у ході якого було здійснено чотири ітерації з метою виокремлення показників із факторною вагою $>0,7$. У результаті було виведено п'ятифакторну емпіричну модель психологічних ресурсів особистості у граничних ситуаціях буття, що кумулятивно пояснювала 79,7\% дисперсії (табл. 1).

Завершальна структура психологічних ресурсів особистості у граничних ситуаціях буття містить психологічні ресурси та показники здатності ними оперувати (любов, відповідальність, знання власних ресурсів, уміння оновлювати власні ресурси, уміння вміщувати власні ресурси), екзистенційні ресурси (милосердя, віра), «сили характеру», що входять до чесноти самовладання (розсудливість, самоконтроль), ресурси взаємин (смислові набуття, екзистенційні набуття). Доцільно звернути увагу, що показники уміння (C) Shtepa Olena

DOI (article): https://doi.org/10.32626/2227-6246.2020-49.407-428 
оперувати ресурсами - знати їх, оновлювати і вміщувати входять до фактора 1 , відтак, є визначальними для функціонування системи психологічних ресурсів особистості у граничних ситуаціях буття.

таблищя 1

Результати багатофакторного аналізу структури психологічних ресурсів особистості у граничних ситуаціях буття

\begin{tabular}{|l|l|l|l|l|l|}
\hline $\begin{array}{l}\text { Психологічні ре- } \\
\text { сурси особистості } \\
\begin{array}{c}\text { у граничних } \\
\text { ситуаціях буття }\end{array}\end{array}$ & $\begin{array}{l}\text { Factor 1 } \\
\mathbf{( 2 8 , 4 \% )}\end{array}$ & $\begin{array}{c}\text { Factor 2 } \\
\mathbf{( 1 5 , 2 \% )}\end{array}$ & $\begin{array}{l}\text { Factor 3 } \\
\mathbf{( 1 3 , 6 \% )}\end{array}$ & $\begin{array}{l}\text { Factor 4 } \\
\mathbf{( 1 2 , 4 \% )}\end{array}$ & $\begin{array}{l}\text { Factor 5 } \\
\mathbf{( 1 0 , 1 \% )}\end{array}$ \\
\hline Любов & $\mathbf{0 , 1 6 8 4 5 9}$ & 0,064447 & 0,083868 & 0,056031 & $\mathbf{0 , 8 9 3 9 2 8}$ \\
\hline Відповідальність & 0,106730 & 0,003063 & 0,040921 & 0,089434 & $\mathbf{0 , 9 0 8 4 8 7}$ \\
\hline $\begin{array}{l}\text { Знання власних } \\
\text { ресурсів }\end{array}$ & $\mathbf{0 , 9 2 4 7 2 4}$ & $-0,019508$ & 0,039905 & 0,103738 & 0,075923 \\
\hline $\begin{array}{l}\text { Уміння оновлюва- } \\
\text { ти власні ресурси }\end{array}$ & $\mathbf{0 , 9 3 4 4 9 2}$ & 0,031325 & 0,050351 & 0,045301 & 0,085940 \\
\hline $\begin{array}{l}\text { Уміння вміщувати } \\
\text { власні ресурси }\end{array}$ & $\mathbf{0 , 8 7 4 2 5 1}$ & $-0,176204$ & 0,001809 & 0,134378 & 0,185323 \\
\hline Милосердя & $\mathbf{0 , 1 1 6 3 4 3}$ & $-0,087477$ & $\mathbf{0 , 8 5 9 6 8 2}$ & 0,056723 & 0,011151 \\
\hline Віра & $-0,043095$ & 0,043604 & $\mathbf{0 , 8 6 4 8 2 3}$ & $-0,042249$ & 0,104036 \\
\hline Розсудливість & 0,085626 & 0,022794 & $\mathbf{0 , 0 4 4 9 4 1}$ & $\mathbf{0 , 8 5 3 7 1 5}$ & 0,097722 \\
\hline Самоконтроль & $\mathbf{0 , 1 2 3 4 3 0}$ & $-0,143419$ & $-0,032533$ & $\mathbf{0 , 8 3 5 8 2 9}$ & 0,038457 \\
\hline Смислові набуття & $-0,039516$ & $\mathbf{0 , 8 4 7 4 0 4}$ & 0,038272 & $-0,043656$ & $-0,015550$ \\
\hline $\begin{array}{l}\text { Екзистенційні } \\
\text { набуття }\end{array}$ & $-0,064986$ & $\mathbf{0 , 8 4 3 5 4 2}$ & $-0,082548$ & $-0,067535$ & 0,078041 \\
\hline
\end{tabular}

За допомогою кластерного аналізу методом $k$-середніх було уточнено, що доцільно характеризувати два типи структури психологічних ресурсів особистості у граничних ситуаціях буття (рис. 1).

(C) Shtepa Olena 


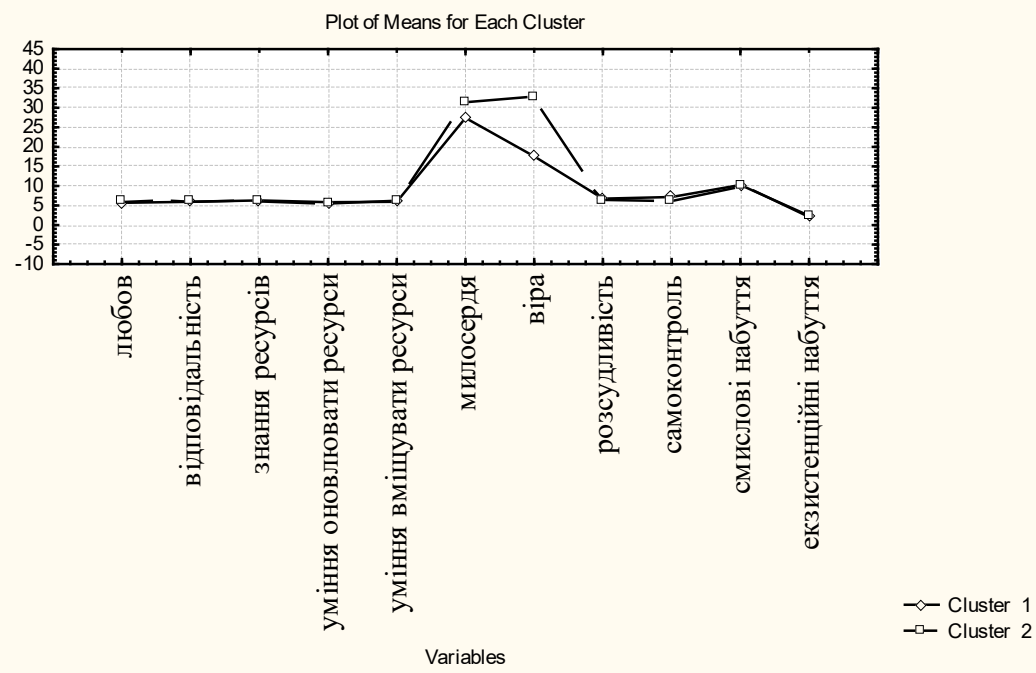

Умовні позначення: cluster 1 - профіль ресурсів самовіднайдення осіб із низьким рівнем екзистенційного ресурсу «віра»; cluster 2 - профіль ресурсів самовіднайдення осіб із високим рівнем екзистенційного ресурсу «віра».

Puc. 1. Типи актуалізації психологічних ресурсів особистості у граничних ситуаціях буття

Визначальним показником виокремлення типу актуалізації психологічних ресурсів особистості у граничних ситуаціях буття виявлено екзистенційний ресурс віри. Високий рівень ресурсу віри, за даними О. Рязанцевої, характеризує властиве особі відчуття зв'язності зі світом, собою і вічністю, а низький рівень ресурсу віри - схильність особи до цинізму, себелюбства й егоцентричності (Рязанцева, 2012: 87). Отже, допустимо характеризувати два типи актуалізування психологічних ресурсів особистості у граничних ситуаціях буття. 3 метою уточнити характеристики визначених типів було застосовано порівняльний аналіз за $t$-критерієм Стьюдента (p $<0,01)$ і встановлено, що особи з вищим рів(c) Shtepa Olena

DOI (article): https://doi.org/10.32626/2227-6246.2020-49.407-428 
DOI: https://doi.org/10.32626/2227-6246.2020-49 2020. випуск 49

нем екзистенційного ресурсу віри (M1 = 32,9), порівняно 3 особами з низьким рівнем ресурсу віри $(\mathrm{M} 2=17,6)$ характеризуються вищим рівнем ресурсу «екзистенційні набуття" $(\mathrm{M} 1=6,0 ; \mathrm{M} 2=2,2)$ і нижчим рівнем ресурсу «відповідальність» $(\mathrm{M} 1=4,5 ; \mathrm{M} 2=6,0)$. Вважаємо, що тип актуалізування психологічних ресурсів особистості у граничних ситуаціях буття, відзначений високим рівнем екзистенційного ресурсу віри, визначається наданням людиною переваги змістовності взаємин над їі прагненням дотримуватися власних переконань.

Із метою охарактеризувати зв'язки між психологічними ресурсами особистості у граничних ситуаціях буття було застосовано кореляційний аналіз (табл. 2).

Доцільно звернути увагу на те, що ресурс віри, рівень якого визначає тип актуалізування психологічних ресурсів особистості у граничних ситуаціях буття, на статистично значущому рівні $(\mathrm{p}<0,001)$ пов'язаний з екзистенційним ресурсом милосердя та психологічним ресурсом любові. Водночас дані кореляційного аналізу показали, що екзистенційний ресурс віри не має зв'язків на статистично значущому рівні $(\mathrm{p}<0,05)$ із показниками уміння людини оперувати власними ресурсами. Виявлено обернені зв'язки між ресурсом взаємин «екзистенційні набуття" i «силою характеру» «самоконтроль», показниками оперування ресурсами (знання власних ресурсів і уміння їх вміщувати), екзистенційним ресурсом «милосердя». Ми пояснюємо обернені зв'язки ресурсів екзистенційного набуття і милосердя тим, що людина робить особистий вклад у взаємини не через емпатію і співчуття (Рязанцева, 2012: 86), які наявні у позиції обміну чи у почутті обов'язку, а як дар, що розкривається у позиції «особистого вкладу» (Петровський, 2014: 105, 106). Обернені зв'язки екзистенційних набуттів зі знанням власних ресурсів і умінням їх уміщувати ми схильні інтерпретувати як ознаки непрагматичності й нераціональності вчинку «особистого вкладу».

(C) Shtepa Olena

DOI (article): https://doi.org/10.32626/2227-6246.2020-49.407-428 
ISSN 2227-6246 (Print)

ISSN 2663-6956 (Online)

ПРОБЛЕМИ СУЧАСНОї ПСИХОЛОГІЇ

DOI: https://doi.org/10.32626/2227-6246.2020-49

2020. ВиПУСК 49

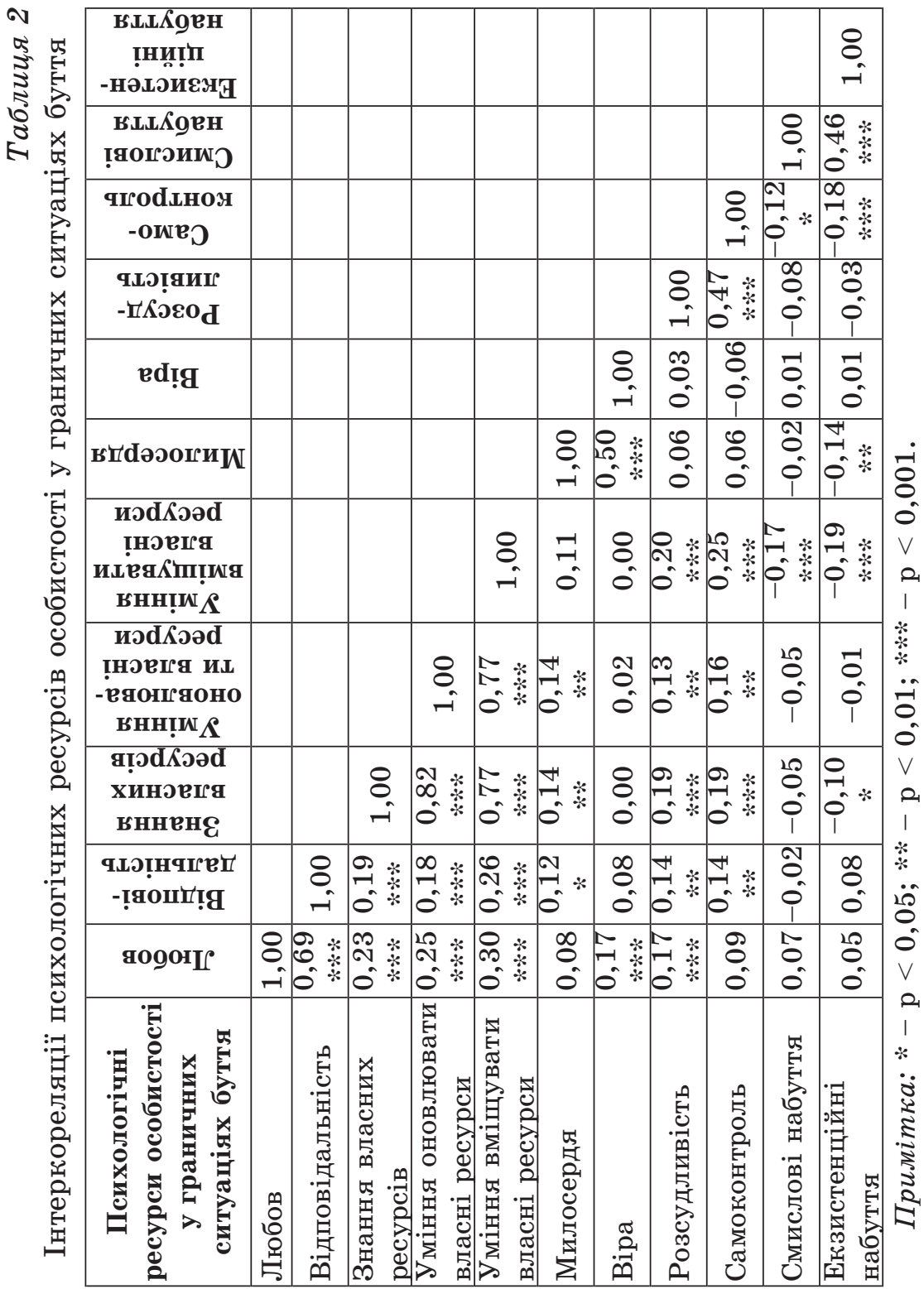

(C) Shtepa Olena

DOI (article): https://doi.org/10.32626/2227-6246.2020-49.407-428 
DOI: https://doi.org/10.32626/2227-6246.2020-49 2020. ВИПУСК 49

Із метою з'ясувати, як психологічні ресурси можуть зумовлювати зміни інтерпретації людиною граничних ситуацій буття, було застосовано класифікаційний аналіз (метод Predictor Variable Rankings) (табл. 3).

Таблиця 3

Результати класифікаційного аналізу психологічних ресурсів як предикторів показників дескриптування граничних ситуацій буття (ранг предиктора*)

\begin{tabular}{|l|c|c|c|c|}
\hline \multirow{2}{*}{$\begin{array}{c}\text { Психологічні } \\
\text { ресурси особистості } \\
\text { у граничних } \\
\text { ситуаціях буття }\end{array}$} & \multicolumn{4}{|c|}{$\begin{array}{c}\text { Показники дескриптування граничних } \\
\text { ситуій бутя }\end{array}$} \\
\cline { 2 - 5 } & $\begin{array}{c}\text { Життє- } \\
\text { стійсть }\end{array}$ & $\begin{array}{c}\text { Особис- } \\
\text { тісна здійс- } \\
\text { ненність }\end{array}$ & $\begin{array}{c}\text { Системна } \\
\text { рефлексія }\end{array}$ & $\begin{array}{c}\text { Відкри- } \\
\text { тість } \\
\text { досвіду }\end{array}$ \\
\hline Любов & 55 & 45 & $\mathbf{9 1}$ & $\mathbf{7 3}$ \\
\hline Відповідальність & 58 & 33 & 44 & 32 \\
\hline $\begin{array}{l}\text { Знання власних } \\
\text { ресурсів }\end{array}$ & 38 & $\mathbf{9 0}$ & 51 & $\mathbf{8 5}$ \\
\hline $\begin{array}{l}\text { Уміння оновлювати } \\
\text { власні ресурси }\end{array}$ & 55 & $\mathbf{1 0 0}$ & 33 & 58 \\
\hline $\begin{array}{l}\text { Уміння вміщувати } \\
\text { власні ресурси }\end{array}$ & $\mathbf{6 1}$ & $\mathbf{6 7}$ & 37 & $\mathbf{8 1}$ \\
\hline Милосердя & $\mathbf{8 1}$ & $\mathbf{7 8}$ & $\mathbf{7 1}$ & $\mathbf{9 6}$ \\
\hline Віра & $\mathbf{1 0 0}$ & $\mathbf{8 5}$ & $\mathbf{1 0 0}$ & $\mathbf{1 0 0}$ \\
\hline Розсудливість & 29 & $\mathbf{6 9}$ & 49 & 48 \\
\hline Самоконтроль & 36 & $\mathbf{6 0}$ & 11 & 26 \\
\hline Смислові набуття & 40 & 45 & 26 & $\mathbf{6 5}$ \\
\hline $\begin{array}{l}\text { Екзистенційні } \\
\text { набуття }\end{array}$ & 42 & 38 & 20 & 36 \\
\hline
\end{tabular}

Примітка: * 0 - min; $100-\operatorname{max.}$

Результати класифікаційного аналізу показали, що головними предикторами ресурсної системи граничних ситуацій буття доцільно вважати екзистенційні ресурси віри і ми-

(C) Shtepa Olena

DOI (article): https://doi.org/10.32626/2227-6246.2020-49.407-428 
лосердя, оскільки вони визначають тренди усіх показників дескриптування граничних ситуацій буття від 71\% до $100 \%$. Психологічний ресурс любові є визначальним для системної рефлексії та відкритості досвіду, «сили характеру» й уміння оперувати власними ресурсами - для особистісної здійсненності. Усі психологічні ресурси особистості у граничних ситуаціях буття досить виразно зумовлюють показники цих ситуацій, а тому зміни системи стають неминучими.

Відповідно, за даними дискримінантного і кореляційного аналізу системоутворювальним чинником ресурсної системи граничних ситуацій буття було допущено знання власних ресурсів і системну рефлексію. Далі було застосовано однофакторний дисперсійний аналіз $(\mathrm{p}<0,01)$, регресійний аналіз $(\mathrm{p}<0,01)$, тест Шеффе $(\mathrm{p}<0,01)$, за результатами яких установлено:

1) знання власних психологічних ресурсів зумовлює зміни усіх компонент ресурсної системи граничних ситуацій буття, за винятком ресурсу взаємин «екзистенційні набуття»; є чинником загального рівня життєстійкості й особистісної здійсненності; є показником, за яким відрізняються між собою підгрупи досліджуваних за такими показниками ресурсної системи граничних ситуацій буття, як ресурси любові, відповідальності, уміння оновлювати і вміщувати власні ресурси;

2) системна рефлексія зумовлює зміни усіх компонент ресурсної системи граничних ситуацій буття; є чинником загального рівня життєстійкості й особистісної здійсненності; є показником, за яким відрізняються між собою підгрупи досліджуваних за усіма компонентами ресурсної системи граничних ситуацій буття.

Відтак, на основі отриманих даних ми зробили висновок, що системоутворювальним чинником ресурсної системи граничних ситуацій буття доцільно вважати системну рефлексію. 


\section{Висновки}

Психологічні ресурси віднайдення людиною самої себе схарактеризовано як структуру взаємопов'язаних психологічних, екзистенційних ресурсів і ресурсів взаємин і «сил характеру», що уможливлюють максимальне наближення «Я»-можливого особи до її істинного «Я» та зумовлюють долання людиною страху самозміни. Наближеність «Я»-можливого особи до її істинного «Я» здійснюється, коли розв’язанням певної життєвої задачі особа долає тривогу.

Структура психологічних ресурсів особистості у граничних ситуаціях буття містить, власне, психологічні ресурси та показники здатності ними оперувати (любов, відповідальність, знання власних ресурсів, уміння оновлювати власні ресурси, уміння вміщувати власні ресурси), екзистенційні ресурси (милосердя, віра), «сили характеру», що входять до чесноти самовладання (розсудливість, самоконтроль), ресурси взаємин (смислові набуття, екзистенційні набуття).

Доцільно зауважити, що ресурси психологічного виживання, толерантності до невизначеності, персональні ресурси, мотиваційні ресурси психологічного благополуччя, відчуття когерентності не увійшли до завершальної моделі психологічних ресурсів самовіднайдення особистості у граничних ситуаціях буття. Причиною цього вважаємо те, що зазначені ресурси актуалізуються за самовизначеності особи, коли вона має змогу порівнювати відоме для неї з новим, психологічні набуття і втрати, зміни значущості для себе певних подій власного життя відносно життєвої перспективи. У ситуаціях граничного буття таке порівняння унеможливлене, оскільки людина переосмислює і власне життя, і саму себе.

Визначальним показником виокремлення типу актуалізації психологічних ресурсів особистості у граничних ситуаціях буття виявлено екзистенційний ресурс віри. За високого рівня екзистенційного ресурсу віри людина надає перевагу змістовності взаємин над іï прагненням дотримуватися

(C) Shtepa Olena

DOI (article): https://doi.org/10.32626/2227-6246.2020-49.407-428 
DOI: https://doi.org/10.32626/2227-6246.2020-49

власних переконань. Головними предикторами ресурсної системи граничних ситуацій буття є екзистенційні ресурси віри і милосердя. Системоутворювальним чинником ресурсної системи граничних ситуацій буття доцільно вважати системну рефлексію.

На підставі результатів емпіричного дослідження можливим є уточнення або розробка психологічного супроводу особистості у складних життєвих ситуаціях.

\section{Література}

Абабков В. А., Перре М. Адаптация к стрессу. Основы теории, диагностики, терапии. Санкт-Петербург : Речь, 2004. 166 с.

Анохин П. К. Принципиальные вопросы общей теории функциональных систем. Принципы системной организации функиий. Москва : Наука, 1973. С. 5-61. URL : www.nemoai.narod.ru.

Бьюдженталь Дж. Искусство психотерапевта. Санкт-Петербург : Питер, 2001. 304 c.

Гришина Н. В. Экзистенциальный опыт: эмпирические описания. Человек, субъект, личность в современной психологии. Материаль международной конференции, посвященной 80-летию А. В. Брушлинского / отв. ред. А. Журавлев, Е. Сергиенко. Москва : Изд-во «Институт психологии РАН», 2013. С. 283-386.

Корнаракис И. Фантастический христианин в сравнении со святоотеческим человеком [пер. с греч. архимандрита Симеона (Гагатика)]. Ахтырка : Ахтырский Свято-Троицкий монастырь, 2016. 160 с.

Леонтьев Д. А., Рассказова Е. И. Тест жизнестойкости. Москва : Смысл, 2006. $63 \mathrm{c}$.

Низовских Н. А. Человек как автор самого себя: психосемантическое исследование личностного развития: монография. Москва - Берлин : Директ-Медиа, 2014. 405 с.

Пушкарев Ю. И. Личность как субъект адаптации и субъект интерпретации: системно-герменевтический подход к изучению личности: монография. Белгород : ИД «Белгород», 2012. 209 с.

Савчин М. Методологеми психології: монографія. Київ : Академвидав, 2013. $224 \mathrm{c}$.

Тітов І. В. Проблема закону в постнекласичній психології. Психологія $i$ особистість. 2015. № 1 (7). С. 30-45.

Хамітов Н., Гармаш Л., Крилова С. Історія філософії. Проблема людини та її меж. Київ : Наукова думка, 2000. $271 \mathrm{c.}$

(c) Shtepa Olena

DOI (article): https://doi.org/10.32626/2227-6246.2020-49.407-428 
Штепа О. С. Головні ідеї інтенціональної концепції особистісного самоздійснення. Проблели сучасної психологї̈: Збірник наукових праць Кам'янеиь-Подільського національного університету імені Івана Огієнка, Інституту психології імені Г. С. Костюка НАПН України / за наук. ред. С. Д. Максименка, Л. А. Онуфрієвої. Кам'янець-Подільський : Аксіома, 2020. Вип. 41. С. 442-461.

Штепа О. С. Опитувальник особистісної здійсненності: теоретичні підстави для розробки та результати апробації. Психологічний часопис: Збірник наукових пращь / за ред. С. Д. Максименка. Київ : Інститут психології імені Г. С. Костюка Національної академії педагогічних наук України, 2018. № 5. Вип. 15. С. 196-223. DOI https://doi.org/10.31108/1.2018.5.15.1.

Штепа О. С. Ресурсна насиченість особистості. Проблеми сучасної ncuхологї: Збірник наукових пращь Кам'янещь-Подільського національного університету імені Івана Огієнка, Інституту психології імені Г. С. Костюка НАПН України / за наук. ред. С. Д. Максименка, Л. А. Онуфрієвої. Кам'янець-Подільський : ТОВ «Друкарня «Рута», 2020. Вип. 47. С. 231-252. DOI https://doi.org/ 10.32626/2227-6246.2020-47.231-252.

Evans, V., \& Green, M. (2006). Cognitive linguistics. An introduction. Edinburgh : Edinburgh University Press Ltd. 830 p.

Markus, H., \& Nurius, P. (1986). Possible selves. American Psychologist, 41 (9), 954-969. URL : https://doi.org.10.1037/0003-066X.41.9.954.

Novak, T., \& Hoffman, D. (2009). The Fit of Thinking Style and Situation: New Measures of Situation-Specific Experiential and Rational Cognition. Journal of Consumer Research. (June). Preprint. URL : https://www.researchgate.net/publication/46553765.

\section{References}

Ababkov, V. A., \& Perre, M. (2004). Adaptatsiia k stressu. Osnovy teorii, diagnostiki, terapii [Adaptation to stress. Fundamentals of theory, diagnosis, therapy]. Sankt-Peterburg : Rech [in Russian].

Anokhin, P. K. (1973). Printsipialnyie voprosy obshchei teorii funktsionalnykh sistem [Fundamental questions of the general theory of functional systems]. Printsipy sistemnoi organizatsii funktsii - Principles of system organization of functions, (pp. 5-61). Moskva : Nauka. Retrieved from www.nemoai.narod.ru [in Russian].

Biudzhental, Dzh. (2001). Iskusstvo psikhoterapevta [The art of a psychotherapist]. Sankt-Peterburg : Piter [in Russian].

Grishina, N. V. (2013). Ekzistentsialnyi opyt: empiricheskiie opisaniia [Existential Experience: Empirical Descriptions]. A. Zhuravliev, (C) Shtepa Olena

DOI (article): https://doi.org/10.32626/2227-6246.2020-49.407-428 
E. Sergiienko (Eds.). Chelovek, subiekt, lichnost $v$ sovremennoi psikhologii - Man, subject, personality in modern psychology: Proceedings of the international conference dedicated to the 80th anniversary of A. V. Brushlinskii, (pp. 283-386). Moskva : Izd-vo «Institut psikhologii RAN» [in Russian].

Kornarakis, I. (2016). Fantasticheskii khristianin v sravnenii so sviatootecheskim chelovekom [Fantastic Christian in comparison with patristic man]. Arkhimandrit Simeon (Gagatik) (Trans.). Akhtyrka : Akhtyrskii Sviato-Troitskii monastyr [in Russian].

Leontiev, D. A., \& Rasskazova, E. I. (2006). Test zhiznestoikosti [Test of Hardiness]. Moskva : Smysl [in Russian].

Nizovskikh, N. A. (2014). Chelovek kak avtor samogo sebia: psikhosemanticheskoie issledovaniie lichnostnogo razvitiia [Man as an author of himself: a psychosemantic study of personal development]. Moskva Berlin : Direkt-Media [in Russian].

Pushkarev, Yu. I. (2012). Lichnost kak subiekt adaptatsii $i$ subiekt interpretatsii: sistemno-germenevticheskii podkhod $k$ izucheniiu lichnosti [Personality as a subject of adaptation and a subject of interpretation: a system-hermeneutic approach to the study of personality]. Belgorod : ID «Belgorod» [in Russian].

Savchyn, M. (2013). Metodolohemy psykholohii [Methodology of Psychology]. Kyiv : Akademvydav [in Ukrainian].

Titov, I. V. (2015). Problema zakonu v postneklasychnii psykholohii [The problem of the law in postnon-classical psychology]. Psykholohiia $i$ osobystist - Psychology and personality, 1 (7), 30-45 [in Ukrainian]. Khamitov, N., Harmash, L., \& Krylova, S. (2000). Istoriia filosofii. Problema liudyny ta yii mezh [History of Philosophy. The problem of a person and his/her boundaries]. Kyiv : Naukova dumka [in Ukrainian]. Shtepa, O. S. (2020). Holovni idei intentsionalnoi kontseptsii osobystisnoho samozdiisnennia [The main ideas of the intentional concept of personality-based self-fulfillment]. S. D. Maksymenko, L. A. Onufriieva (Eds.). Problemy suchasnoi psykholohii - Problems of modern psychology: Collection of research papers of Kamianets-Podilskyi National Ivan Ohiienko University, G. S. Kostiuk Institute of Psychology of the National Academy of Educational Sciences of Ukraine, 41, pp. 442-461. Kamianets-Podilskyi : Aksioma [in Ukrainian].

Shtepa, O. S. (2018). Opytuvalnyk osobystisnoi zdiisnennosti: teoretychni pidstavy dlia rozrobky ta rezultaty aprobatsii [The questionnaire of a personality fulfillment: the theoretical grounds for creation and the results of approbation]. S. D. Maksymenko (Ed.). Psykholohichnyi chasopys - Psychological journal, 5 (15), 196-223. Kyiv : Instytut psy-

(c) Shtepa Olena

DOI (article): https://doi.org/10.32626/2227-6246.2020-49.407-428 
kholohii imeni H. S. Kostiuka Natsionalnoi akademii pedahohichnykh nauk Ukrainy. DOI https://doi.org/10.31108/1.2018.5.15.1 [in Ukrainian].

Shtepa, O. S. (2020). Resursna nasychenist osobystosti [Resource's Richness of Personality]. S. D. Maksymenko, L. A. Onufriieva (Eds.). Problemy suchasnoi psykholohii - Problems of Modern Psychology: Collection of research papers of Kamianets-Podilskyi National Ivan Ohiienko University, G. S. Kostiuk Institute of Psychology of the National Academy of Educational Sciences of Ukraine, 47, 231-252. Kamianets-Podilskyi : TOV «Drukarnia Ruta». DOI https://doi.org/ 10.32626/2227-6246.2020-47.231-252 [in Ukrainian].

Evans, V., \& Green, M. (2006). Cognitive linguistics. An introduction. Edinburgh : Edinburgh University Press Ltd.

Markus, H., \& Nurius, P. (1986). Possible selves. American Psychologist, 41 (9), 954-969. Retrieved from https://doi.org.10.1037/0003066X.41.9.954.

Novak, T., \& Hoffman, D. (2009). The Fit of Thinking Style and Situation: New Measures of Situation-Specific Experiential and Rational Cognition. Journal of Consumer Research, 36 (1), 56-72. Preprint. Retrieved from https://www.researchgate.net/publication/46553765.

\section{Штепа Олена. Психологічні ресурси самовіднайдення особистості у гра- ничних ситуаціях буття}

\section{АНОТАЦІЯ}

Мету дослідження визначено як емпіричне дескриптування психологічних ресурсів особистості у граничних ситуаціях буття.

Методи. Застосовано психологічне опитування з використанням таких методик, як опитувальник персональної ресурсності, опитувальник психологічної ресурсності, тест-опитувальник діагностики показників екзистенційних ресурсів, анкета чеснот і "сил характеру», опитувальник стратегій подолання кризового стану, опитувальник психологічного благополуччя, шкала когерентності, методика визначення (ін) толерантності до невизначеності, методика оцінки та прогнозування психологічного розвитку ситуацій міжособистісної взаємодії. Застосовано такі методи математико-статистичного аналізу, як однофакторний дисперсійний аналіз, багатофракторний аналіз, кластерний аналіз, класифікаційний аналіз, кореляційний аналіз. Для реалізації завдань дослідження застосовано модель Байєра, яка передбачає перетворення про-

(C) Shtepa Olena

DOI (article): https://doi.org/10.32626/2227-6246.2020-49.407-428 
DOI: https://doi.org/10.32626/2227-6246.2020-49 2020. ВиПУСК 49

блеми до уможливлюваного для розв'язання вигляду. Реалізовано методи емпіричного моделювання та верифрікації.

Результати дослідження. На основі даних дискримінантного і багатофракторного аналізу визначено структуру психологічних ресурсів особистості у граничних ситуаціях буття, яка містить, власне, психологічні ресурси та показники здатності ними оперувати (любов, відповідальність, знання власних ресурсів, уміння оновлювати власні ресурси, уміння вмішувати власні ресурси), екзистенційні ресурси (милосердя, віра), «сили характеру», що входять до чесноти самовладання (розсудливість, самоконтроль), ресурси взаємин (смислові набуття, екзистенційні набуття). Визначальним показником виокремлення типу актуалізації психологічних ресурсів особистості у граничних ситуаціях буття виявлено екзистенційний ресурс віри. Системоутворювальним чинником ресурсної системи граничних ситуацій буття визначено системну рефлексію. Психологічні ресурси віднайдення людиною самої себе схарактеризовано як структуру взаємопов'язаних психологічних, екзистенційних ресурсів і ресурсів взаємин $і$ "сил характеру», що уможливлюють максимальне наближення «Я»-можливого особи до ії істинного «Я» та зумовлюють долання людиною страху самозміни.

Висновок. Наближеність "Я»-можливого особи до ії істинного «Я» здійснюється, коли розв'язанням певної життєвої задачі особа долає тривогу. Ресурси психологічного виживання, толерантності до невизначеності, персональні ресурси, мотивачійні ресурси психологічного благополуччя, відчуття когерентності не увійшли до завершальної моделі психологічних ресурсів самовіднайдення особистості у граничних ситуаціях буття, оскільки у ситуаціях граничного буття унеможливлене порівняння людиною психологічних набуттів і втрат, тому що вона переосмислює і власне життя, і саму себе. На підставі результатів емпіричного дослідження можливим $є$ уточнення або розробка психологічного супроводу особистості у складних життєвих ситуаціях.

Ключові слова: психологічні ресурси самовіднайдення особистості, граничні ситуації буття, життєстійкість, особистісна здійсненність, системна реслексія.

\section{Штепа Елена. Психологические ресурсы самообретения личности в граничных ситуациях бытия}

(C) Shtepa Olena

DOI (article): https://doi.org/10.32626/2227-6246.2020-49.407-428 
ISSN 2227-6246 (Print)

ISSN 2663-6956 (Online)

ПРОБЛЕМИ СУЧАСНОї ПСИХОЛОГІї

DOI: https://doi.org/10.32626/2227-6246.2020-49

2020. випуск 49

\section{АННОТАЦИЯ}

Цель исследования определена как эмпирическое дескриптирование психологических ресурсов личности в граничных ситуациях бытия.

Методы. Применен психологический опрос с использованием опросника персональной ресурсности, опросника психологической ресурсности, тест-опросника диагностики показателей экзистенциальных ресурсов, опросника добродетелей и "сил характера», опросника стратегий преодоления кризисного состояния, опросника психологического благополучия, икалы когерентности, методики определения толерантности к неопределенности, методики оценки и прогнозирования развития ситуаций межличностного взаимодействия. Применены такие методы математико-статистического анализа, как однофакторный дисперсионный анализ, многофакторный анализ, кластерный анализ, классификационный анализ, корреляционный анализ. Для реализации заданий исследования применена модель Байера, предполагающая преобразование проблемы в возможный для ее разрешения вид. Реализованы методы эмпирического моделирования и верификации.

Результаты исследования. На основе данных дискриминантного и многодракторного анализа определена структура психологических ресурсов личности в граничных ситуациях бытия, которая вмещает, собственно, психологические ресурсы и показатели способности ими оперировать (любовь, ответственность, знание своих ресурсов, умение обновлять и вкладывать свои ресурсы), экзистенциальные ресурсы (милосердие, вера), «силы характера», входящие в добродетель самообладания (рассудительность, самоконтроль). Показателем определения типа актуализации психологических ресурсов личности в граничных ситуациях бытия установлено экзистенциальный ресурс веры. Системообразующим фактором ресурсной системы граничных ситуаций бытия эмпирически обосновано системную рефлексию. Психологические ресурсы самообретения личности охарактеризовано как структуру взаимосвязанных психологических, экзистенциальных ресурсов и ресурсов взаимоотношений и "сил характера», делающих возможным максимальное приближение "Я»-возможного личности кее истинному “Я» и обуславливающих преодоление человеком страха самоизменений.

Вывод. Приближенность «Я»-возможного личности к ее истинному "Я» осуществляется, когда решением некоторой жизненной задачи человек преодолевает тревогу. Ресурсы психологического выживания, (C) Shtepa Olena

DOI (article): https://doi.org/10.32626/2227-6246.2020-49.407-428 
DOI: https://doi.org/10.32626/2227-6246.2020-49 2020. ВипУСК 49

толерантности к неопределенности, персональные ресурсы, мотивационные ресурсы психологического благополучия, чувство связности не вошли в завершальную модель психологических ресурсов самообретения личности, поскольку в граничных ситуациях бытия невозможно сравнение человеком психологических потерь и приобретений, ведь он переосмысливает и свою жизнь, и себя самого. На основании результатов эмпирического исследования возможно уточнение или разработка психологического сопровождения личности в сложных жизненных ситуациях.

Ключевые слова: психологические ресурсы самообретения личности, граничные ситуации бытия, жизнестойкость, личностная исполненность, системная рефлексия.

Original manuscript received April 19, 2020 Revised manuscript accepted May 26, 2020 